\title{
On a Collection of Birds from Celebes and Halmahera, preserved in Yamashina Meseum of Birds. (Non-Passeres, II)
}

\author{
Nagahisa KUrodA
}

\section{PODICIPIDAE}

52. Podiceps ruficollis tricolor G.R. Gray

Podiceps (Sylbeocyclus) tricolor G.R. Gray, Pr. Z.S. London, 1860 (1861), p. 266 (Ternate).

Halmahera is 9, xii, 1934

A race for Celebes, the Moluccas, New Guinea to Bismark Archipelago and the Solomon Is.

\section{SULIDAE}

53. Sula leucogaster plotus (Forster)

Pelecanus Plotus Forster, Descr. Anim., ed. Licht., p. 278 (Near New Caledonia).

Celebes $\quad 3 \quad 1928$

ANATIDAE

54. Dendrocygna guttata Schlegel

Dendrocygna guttata Schlegel, Mus. Pays-Bas, 6, 1866, Anseres, p. 85. (Celebes).

Halmahera 19, xii, 1934

3 호하, 2 우 $\quad$ ix, xi (1우), 1936

4 우 우 29, iii, 11, 19, iv, 1937

$3 \dot{\delta}$, 3 우 undated

$3 \hat{s} \hat{o}$ juvs. undated

Celebes (Mongondo) 2 downy chicks 8, v, 1937

No locality 4 unsexed undated

A species distributed from Mindanao, Celebes and the Moluccas to New Guinea, also Bismark Archipelago.

55. Tadorna radjah radjah (Lesson)

Anas radjah “Lesson and Garnot", Lesson, Man. d’Orn., 2, 1828, p. 417 (Buru). 


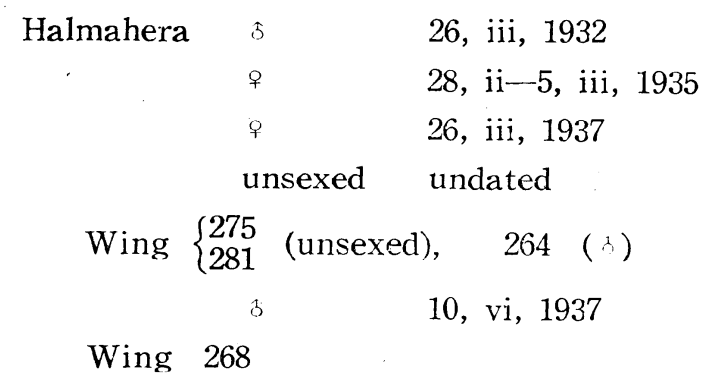

A race for the Moluccas and New Guinea with the other race in Australia. The last specimen (labelled as "Celebes"=error, Halmahera!) has the greater wing-coverts not pure white but is greyish towards the narrow subterminal black band, the dark breast band being almost lacking (by loss of feathers?). This may not be a young bird for it has white head.

\section{ARDEIDAE}

Genus Ardea Linné, 1758

Type, Ardea cinerea Linné

56. Ardea sumatrana sumatrana Raffles

Ardea Sumatrana Raffles, Trans. Linn. Soc. London, 13, pt. 2, 1822, p. 325 (Sumatra).

$$
\text { Halmahera } \quad \text { 28, ii }-5 \text {, iii, } 1935
$$

The species ranges in two races from Burma to the Philippines, Borneo, the Moluccas, New Guinea and Australia, but lacking in Celebes.

Genus Egretta Forster, 1817

Type, Ardea garzetta Linné

(57). Egretta alba modesta (Gray)

$\begin{array}{lll}\text { Halmahera } & 2 \text { unsexed } & \text { vi, } 1936 \\ & \text { is } & \text { ix, } 1936\end{array}$

Stresemann ('41, p. 7) makes it a breeding bird in Celebes, though is only known from the northern peninsula.

58. Egretta intermedia intermedia (Wagler)

Ardea intermedia Wagler, Ibis, 1829, p. 659 (Java).

Celebes (Mongondo) \& 26, iv, 1937

It is reported as breeling in Celebes (Stresemann, '41, p. 7).

59. Egretta garzetta nigripes (Temminck)

Ardea nigripes Temminck, Man. d'Orn., ed. 2, 4, 1840, p. 376 (Sunda Is.)

Halmahera $q$ undated 
A black-toed race of garzetta ranging in the Philippines, Celebes, the Moluccas, Sunda Is. and New Guinea.

Genus Bubulcus Bonaparte, 1855

Type, Ardea ibis Linné

60. Bubulcus ibis coromandus (Boddaert)

Cancroma Coromanda Boddaert, Tabl. P1. Enlum., p. 54, 1783 (Coromandel).

Halmahera s, 3 우 우 3 unsexed iv, vi, ix, 1936

i undated

Celebes (Minahasa) is, क $9,16, \mathrm{v}, 1938$

A widely distributed race, but may be new to Halmahera.

Genus Demigretta Blyth, 1846

Type, Ardea sacra Gmelin

61. Demigretta sacra sacra (Gmelin)

Ardea sacra Gmelin, Syst. Nat., 1, pt. 2, 1789, p. 640 (Tahiti).

Celebes (Minahasa) i $\quad 15$, viii, 1937

Genus Dupetor Heine and Reichenow, 1890

Type, Ardea flavicollis Latham

62. Dupetor flavicollis gouldi (Bonaparte)

Ardetta gouldi Bonaparte, Consp. Av., 2, 1855, p. 132 (New South Wales).

Halmahera of

16, iv, 1937

7, vi, 1937

2 क $\delta$ juvs. (one black phase)

$19,25, \mathrm{v}, 1937$

The race flavicollis has chestnut spots of the throat, with cheeks black in adults and chestnut in young, while in gouldi both spots and cheeks are black in the adults and young. The nominal race ranges from India to Celebes and gouldi from the Moluccas to Australia. A specimen (No. 28326) is a very young bird having buffish margin of the feathers with buffish scales on the cheeks and spots of the throat, while the other is a young of all-dark plumage (=' melaena').

Stresemann states that in Celebes this 'melaena' doesn't occur though is known from Halmahera.

Genus Nycticorax T. Forester, 1817

Type, Ardea nycticorax Linné

63. Nycticorax caledonicus minahasae Meyer and Wiglesworth

Nycticorax minahasae Meyer and Wiglesworth, Jonrn. f. Orn., 42, 1894, p. 
115 (Kema, N. Celeles). Cf. Riley, Pr. U.S. Nat. Mus., 64, art. 16, 1924, pp. 30-31.
Celebes (Minahasa)
3, vii, 1938

Genus Butorides Blyth, 1852

Type, Ardea javanica Horsfield

64. Butorides striatus moluccarum Hartert

Butorides striatus moluccarum Hartert, Vög. pal. Faun., 2, 1920, p. 1251 (Buru).

$\begin{array}{lll}\text { Halmahera } & 2 \delta \delta, \delta \text { juv. } & \text { 15, 18, xii, } 1934 \\ 2 \text { unsexed } & \text { ix, 1936 } \\ & \text { so, iii, 1937 } \\ & + & \text { undated }\end{array}$

Wing 172-184 Tarsus 45-50.2 Culmen'depth at base $63.5-67.5 / 12-14$

Peters gives Buru, Ceram and Amboina (also Obi ?) for its range, and Halma. hera should be added by the above records.

65. Butorides striatus (?)javanicus (Horsfield).

Ardea Javanica Horsfield, Trans. Linn. Soc. London, 13, 1821, p. 190 (Java).

Celebes (Minahasa)

$$
\begin{aligned}
& \text { 5, viii, } 1937 \\
& 4 \text { 항, } 5 \text { ㅇ } 7,15,18,19, \mathrm{v}, 18,22 \text {, vii, } \\
& \text { 3, 5, 18, viii, } 1938 \\
& 2 \text { 우 우 juvs. 2, 29, vii, } 1938
\end{aligned}
$$

Wing 158, 165 (o juvs), 168177 Tarsus 42.546

Culmen/depth at base 54-63 11-12

This race ranges widely from India to the Philippines, Sunda Is., and Celebes. The measurements of Celebesian specimens given by Stresemann are; 4 s 5 , wing $172,176,178,178$; and Meyer \& Wiglesworth give: wing 160-168 (juvs), 167-174 (vid ads), 180-182 (ads), tarsus 44-48, culmen 52 (juv)-62, in 13 specimens.

Nine Formosan specimens ( $2 \delta$ bads, 2 subads, 5juvs) measure ; wing 156 (juvs), 170-185 (exceptional 193), tarsus 45 (juvs) 50, culmen depth at base 52 (juvs) -64 11.5 (juvs)-13. Thus, although the Formosan birds are similar in color to Celebesian javanicus, they are apparently larger in size and are thicker billed, though the Celebes specimens may sometimes be almost as large as the Formosan birds according to the measurements given by Meyer \& Wiglesworth (wing length and tarsus). The bill length, however, rarely exceeds $60 \mathrm{~mm}$. in Celebesian specimens, while it is usually over $60 \mathrm{~mm}$. in Formosan birds, and the bill is appasently slender in the former.

As to the measurements of Sunda Is. birds, Dr. Kuroda, Sr. (Bds. Java) re- 
ports as follows: Java $q$, wing 181, tarsus 50, culmen 64; wing 157-180 (Stresemann), 162-169 (Van Oort $\%$ Bali o , wing 155 (von Plessen).

The Formosan population may be separable as larger and thicker-billed northern race, but whether the smaller and thinner-billed Celebesian birds are similar to the typical Javan form is still unclear.

Genus Ixobrychus Billberg, 1828

Type, Ardea minuta Linné

66. Ixobrychus sinensis sinensis (Gmelin)

Ardea Sinensis Gmelin, Syst. Nat., 1, pt. 2, 1789, p. 642 (China).
Halmahera o
ix, 1936
Celebes (Kema) unsexed
4, vi, 1889 (Rosenberg)

A race of China, India to Malay Archipelago. Mayr ('41) does not recognize the races.

\section{FALCONIDAE}

Subfamily Buteoninae

Genus Haliaeëtus Savigny, 1809

Type, Falco albicilla Linné

Subgenus Cuncuma Hodgson, 1837

Type, Falco leucoryphus Pallas

67. Haliaeёtus leucogaster (Gmelin)

Falco leucogaster Gmelin, Syst. Nat., 1, pt. 1, 1788, p, 257

(New South Wales, fide Mathews, Nov. Zool., 1912, p. 248).

$\begin{array}{lll}\text { Halmahera } & \text { q } & 28, \text { ii }-5, \text { iii, } 1935 \\ & 2 \text { 우 } & 29, \text { iii, } 7, \text { iv }, 1937 \\ \text { Celebes } & 5 & 29, \text { iv } 1937\end{array}$

Celebes is 29, iv, 1937

A species widely distributed from India, Malay Archipelago to Australia, and also western Polynesia.

Genus Spizaëtus Vieillot, 1816

Type, Falco ornatus Daudin

68. Spizatëus lanceolatus Temminck \& Schlegel

Spizaëtus lanceolatus Temminck \& Schlegel, in Siebold, Fauna Jap., Aves, 1844, p. 7 in text (Celebes).

Celebes (Minahasa) is 22, viii, 1938

A species restricted to Celebes, and Sula-Besi and Peling. Peters makes it a race of nipalensis, but Stresemann ('40, pp. 469-470) consider's it a valid species. 


\section{Subfamily Circaetinae}

Genus Spilornis G.R. Gray, 1840

Type, Falco bassus J.R. Forster

69. Spilornis rufipectus rufipectus Gould

Spilornis rufipectus Gould, Pr. Z.S. London, 1857, p. 222 (Macassar).

Celebes (Minahasa) juv. 20, viii, 1938

A species restricted to a part of Borneo, Celebes and Sula Is., and the present race is endemic to Celebes.

Subfamily Perninae

Genus Aviceda Swainson, 1836

Type, Aviceda cuculoides Swainson

70. Aviceda subcristata rufa (Schlegel)

Baza rufa Schlegel, Vog. Ned. Ind. Valkvog., 1866, p. 41, 78, pl. 27, f. 4; pl. 28, f. 1-3 (Halmahera, Morotai, Batjan, Ternate, Tidore).

$\begin{array}{ccl}\text { Halmahera } & \text { unsexed } & \text { ix }, 1936 \\ & \text { o } & 3, \mathrm{v}, 1937 \\ & \text { unsexed } & \text { undated }\end{array}$

Against the species jerdoni which is distributed from India to the Philippines, Celebes and Borneo, the present species occupies Sunda Is., Moluccas south to New Guinea and Australia. The Moluccan race, A. s. rufa, has doubtfully been reported from Celebes. Meyer \& Wiglesworth (1898, I, pp. 77-8) give few old specimens as probably fiom Celebes, though they regard them to be "almost certainly erroneous".

\section{Subfamily Milvinae}

Genus Haliastur Selby, 1840

Type, Falco indus Boddaert

\section{Haliastur indus girrenera (Vieillet)}

Haliastur girrenera Vieillot, Gal. Ois., 1, 1822, p. 31, pl. 10 (New South Wales, fide Peters, I, p. 205).

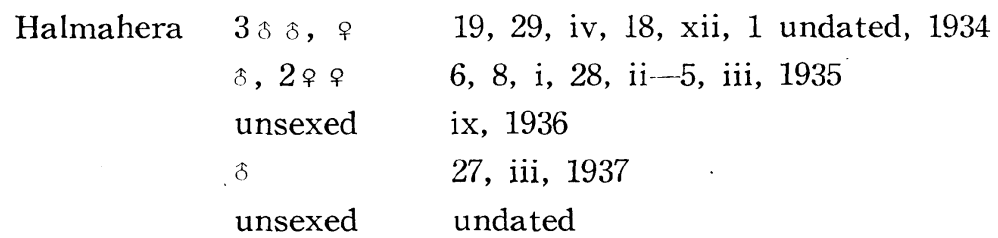

These specimens have no black shaft of the feathers except in two specimens 
only (males), in which slight black shafts are present on the back.

72. Haliastur indus ambiguus Brüggemann

Haliastur indus var. ambiguus Brüggemann, Abb. Nat. ver. Bremen, Bd. v, 1875 , p. 45, 1876 (Celebes).

Celebes (Menado, Minahasa, Inubont)

$$
\begin{array}{ll}
2 \text { 우 } & 4,12, \text { viii, } 1937 \\
5 & 27, \text { vi, } 1938 \text { (Inubont) }
\end{array}
$$

In these specimens dark shafts are present on the head and are lacking on the breast.

Note: The above two races are dark backed and, as Stresemann states ('40, p. 479), the race ambiguus can be recognized. A specimen from Mindanao can be identified as intermedia being characterized by weak streaks on the white head and breast, and the chestnut color of the back is paler with also slight streaks. Two Indian and one Siamese specimens are heavily streaked on the white parts, and the back is pale as in Mindanao specimen, also having slight streaks. They belong to the race indus (also cf. Cat. Bds. Brit. Mus., I, p. 314). The measurements are as follows:

\begin{tabular}{llll}
\multicolumn{1}{c}{ Locality } & \multicolumn{1}{c}{ Wing } & \multicolumn{1}{c}{ Tail } & \multicolumn{1}{c}{ Race } \\
Halmahera & $342-361$ & $154-187$ & girrenera $(10 \mathrm{spec})$. \\
Celebes & $342-400$ & 191,201 & ambiguus $(3 \mathrm{spec}$ ) \\
Mindanao & 378 & $200+\mathrm{x}$ & intermedia $(1 \mathrm{spec})$. \\
Siam & 371 & 293 & indus $(1 \mathrm{spec})$. \\
India & 366,373 & $183.5,200$ & indus $(2 \mathrm{spec})$.
\end{tabular}

Subfamily Accipitrinae

Genus Accipiter Brisson, 1760

Type, Falco nisus Linné

$$
\text { (Astur-Group) }
$$

73. Accipiter novaehollandiae griseogularis (G.R. Gray)

Astur griseogularis G.R. Gray, Pr. Z.S. London, 1860, p. 343 (Batjan, Gilolo and Ternate)

Synonyms :

Accipiter aequatorialis Wallace, Pr. Z.S. London, 1865, p. 474; Ibis, 1868, p. 10 (=male!)

Astur henicogrammus Sharpe, Cat. Bds. Brit. Mus., 1874, p. 124 (part: description of the adult).

Astur muelleri Sharpe, Ibid., p. 103 (description of the young)

$$
\begin{array}{lll}
\text { Halmahera } & \text { f } & 15, \text { xii, } 1932 \\
& 3 q \text { o } & 29, \text { iii, } 7, \text { iv }, 20, \text { vi, } 1937
\end{array}
$$




$$
\begin{aligned}
& \text { क juv. } \quad 7 \text {, vi, } 1937 \\
& \text { “q" ( } \delta \text { subad. !) undated } \\
& \text { unsexed ( }+ \text { !) undated }
\end{aligned}
$$

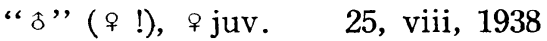

Wing 223-225 (ㅎㅎ), 251-264 (웅) Tail 168-183.5 (ㅎㅎ),

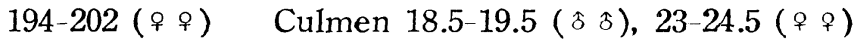

Tarsus 62 (ㅅํ), 71 (우) Middle toe without claw 33-37 (하), 44-45 (ㅇ ㅇ ).

As shown in the synonyms, much confusion is found in the name of this species, for the size difference by sex is extremely great, the male being as small as A. henicogramma. This confusion has correctly been settled by Salvadori (Orn. d. Papuas et de Molucche, I, 1880, pp. 54-56, 57-60).

This species is characterized by a vinous collar round the nape and is a member of the "Formenkreis" of $A$. novaehollandiae-A. fasciata, each with many subspecies, and each group is characterized by the color of cere, wing formula and the presence or absence of the vinous collar (cf. Stresemann, Journ. f. Orn., 1924, pp, 444 446).

The young (No. 34200, of) is brown on the upperparts lacking ashy tinge, the second year young (No. 34257, क) has the head greyish with much white at the base of feathers, and has vinous chestnut collar on the nape. The cheek is pale grey and the throat almost white at the center, the underparts being buffish white, heavily barred with vinous chestnut (with dark margine) on the upper breast, and the lower parts are spotted. Thigh is more buffish with rusty bars.

The species novaehollandiae is of Austro-Moluccan (including Sunda Is.) distribution and the race griseogularis is a Moluccan form.

74. Accipiter henicogramma (G.R. Gray)

Astur henicogramma G.R. Gray, Pr. Z.S, London, 1860, p. 343 (East Gilolo)

(Type is a young specimen!)

Synonyms :

Accipiter muelleri Wallace, Pr. Z.S. London, 1865, p. 474 ; Ibis, 1868, p. 9 (Adult specimen!); Sharpe, Cat. Bds. Brit. Mus., 1874, p. 102 (part: description of the adult bird).

Astur henicogramma Sharpe (not of Gray), Ibid., 1874, p. 124 (part; description of the young bird, ex Gray's type).

$$
\begin{array}{lll}
\text { Halmahera } & \text { के } & \text {-12, ii, } 1935 \\
& \text { “负” (ㅇ ?) } & \text { undated }
\end{array}
$$

Celebes (Gorontaro, Mongondo)

$$
\text { o juv. (s ?) 16, vi, } 1937
$$

Wing 211-246 Tail 188, $197 \quad$ Culmen 16.5 
Tarsus 67.5-70.5 Middle toe without claw 30.5-33

This is a much smaller species of about the size of the male of A. $n$. griseogularis. It can be easily identified from that species (or the "Formenkreis" novaehollandiae fasciata) by:1) the primaries are not abruptly emerginated on the inner web, 2) uniformly very dark slaty (not pale ashy) upperparts, without a vinous collar on the hind neck, 3) throat is mixed with some white and chestnut color (not uniformly pale buffish ashy color), 4) under surface is rich chestnut color with faint narrow whitish bars (not pale vinous buff), 5) very slender and long tarsus with smaller toes, and 6) proportionally very long tail. The young are brown and barred on the whole upperparts (not plainly brown) and the throat is streaked, the underparts being barred without spots.

The proportional difference in measurements are as follows:

Wing/tail Wing Tarsus, Tarsus/Mid. toe

$\begin{array}{lccc}\text { A. } n \text {. griseogularis } & 1.26-1.32 & 3.53-3.78 & 1.55-1.87 \\ \text { A. n. fasciata } & 1.34 & 3.31 & 1.77 \\ \text { A. henicogramma } & 1.16-1.24 & 3.27-3.48 & 2.13-2.21\end{array}$

A. hecniogramma is a Moluccan species.

75. Accipiter trinotatus trinotatus Bonaparte

Accipiter trinotatus Bonaparte, Consp. Av., 1, 1850, p. 33 (Celebes)

Celebes (Minahasa and Mongondo)

$$
\begin{aligned}
& 2 \text { 하, } 2 \text { 우우, 占 juv. 9, } 10, \mathrm{v}, 30, \mathrm{vi}, 10 \text {, vii, } \\
& \text { 12, viii, } 1938
\end{aligned}
$$

An endemic species of Celebes, the present race occupying the most part except southern district where haesitandus occurs.

It is characterized by large white spots (two exposed) of the tail. The adult is slaty black above with salmon-colored underparts and the young are chestnut on the upperparts, head with dark stripes, tail black (with large white spots), edged with rusty color, the outermost rectrices being chestnut. Shaft of primaries black above, and white below, the throat is buffish with dark stripes, breast to flanks buffish and striped. The southern race is said to be distinguishable only in the richer buffish underparts in the young.

76. Accipiter griseiceps (Schlegel)

Astur griseiceps Schlegel, Mus, Pays-bas, 2, 1862, Astures, p. 23 (N. Celebes). Celebes (Amurang, Minahasa) o 19 , vii, 1938

An endemic species of Celebes. The head is grey, all upperparts brown, tail indistinctly barred, all underparts white, breast and flanks with broad stripes, and the thigh is narrowly barred. The tarsus and toes are short.

(77). Accipiter soloënsis (Horsfield) 
Halmahera $\quad$ juv. 18, i, 1935

A winter migrant probably from China.

\section{(Accipiter-Group)}

78. Accipiter rhodogaster rhodogaster (Schlegel)

Nisus virgatus rhodogaster Schlegel, Mus. Pays-Bas, 2, 1862, Astures, p. 32 (Gorontaro, Celebes).

Celebes (Amurang, Minahasa) $\odot$ juv. 15, vii, 1938

An endemic race to Celebes and Banggai, with the other race in Sula Is. (sulaensis). Peters regards them as conspecific with virgatus. Has very long Accipiter-type tarsi and toes. The present young specimen is bright buffish chestnut above with subterminal black spots, the head is almost black with buffishchestnut margine of the feathers, tail and wings are distinctly barred with black. Underparts are creamy white with broad blackish and rusty stripes. The adult is said deep bluish grey above.

79. Accipiter erythauchen erythauchen G.R. Gray

Accipiter erythauchen G.R. Gray, Pr. Z.S. London, 1860, p. 344 (E. Gilolo).

$\begin{array}{lll}\text { Halmahera } & 1 \text { juv. } & \text { ix, } 1936 \\ & \circ \text { juv. } & 29, \text { iii, } 1937 \\ & \$ & 15, \text { v }, 1937\end{array}$

This Moluccan species comprises two races, the northern (Halmahera, Batjan, Obi) and southen (Ceram, Buru-ceramensis). The tarsi are extremely long. A very small sized species.

\section{Subfamily Pandioninae}

Genus Pandion Savigny, 1809

Type, Falco haliaetus Linné

80. Pandion haliaetus cristatus (Vieillot)

Buteo cristatus Vieillot, Nouv. Dict. Hist. Nat., 4, 1816, p. 4ö: (Tasmania, fide Mathews).

$\begin{array}{lll}\text { Halmahera } & \text { unsexed } & \text { ix, } 1936 \\ \text { Celebes } & \hat{\delta} & 13, \mathrm{v}, 1938\end{array}$

An Austro-Malaysian race.

\section{STRIGIDAE}

Genus Ninox Hodgson, 1837

Type, Ninox nipalensis Hodgson

(Subgenus Spiloglaux Kaup, 184ð)

Type, Strix boobook Latham 
81. Ninox squamipila hypogramma (Gray)

Athene hypogramma Gray, Pr. Z.S. London, 1860, p. 344 (Batjan).

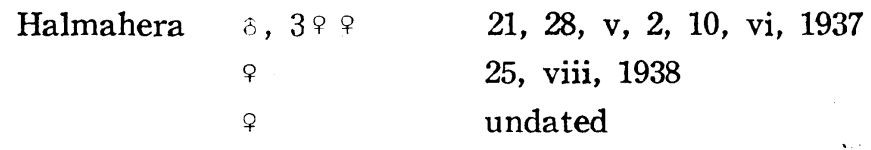

Wing 216-230 Tail 123.5-139 Culmen 16.2-18

Tarsus $33.5-35$

The Spiloglaux is an Austro-Malaysian group and the present species is only known from Batjan and Halmahera. Two of the specimens lack any bars on the central rectrices, while they are most distinct in a female which is small in measurements (a younger bird?).

(Subgenus Ninox Hodgson)

82. Ninox perversa Stresemann

Ninox perversa Stresemann, Orn. Mon., 46, p. 149, 1938

(New name for Noctua ochracea Schlegel, 1866-N. Celebes).

Celebes (Minahasa, one from Mongondo)

$$
\text { ㅎ } 2 \text { 우 우 } 7, \mathrm{v}, 8,10 \text {, vii, } 1938
$$

An endemic Celebesian species. The male is almost uniform ochreous chestnut color on the undersurface and the white spots on the wings and tail (inner basal part only) are very small and indistinct, the female is paler below with distinct darker stripes and the white markings on the wings and tail are conspicuous, while the young (with silky feathers on the underparts) is still paler below and has distinct white markings as in the female.

(Subgenus Cephaloptynx Kaup, 1852)

Type, Noctua punctulata Q. et Gaim.

83. Ninox punctulata (Quoy et Gaimard)

Noctua punctulata Quoy et Gaimard, Voy. Astrol., Zool., 1, p. 165, 1830, pl. 1, fig. 1 (Celebes).

Celebes (Minahasa) . o $\quad$ 17, vi, 1938

An endemic Celebesian species.

(Subgenus Hieracoglaux Kaup, 1848)

Type, Falco connivens Latham

84. Ninox connivens rufistrigata (Gray)

Athene rufistrigata Gray, Pr. Z.S. London, 1860, p. 344 (E. Gilolo)

Halmahera $\quad$ P

25, vii, 1938

An endemic Halmaheran species. 


\author{
Genus Otus Pennant, 1769 \\ Type, Otus bakkamoena Pennant \\ (Subgenus Pisorhina Kaup, 1848) \\ Type, Scops manadensis $\mathbf{Q}$. et G.
}

85. Otus manadensis leucospila (Gray)

Ephialtes leucospila Gray, Pr. Z.S. London, 1860, p. 344 (Batjan and Gilolo). Halmahera $\&$ downy with wing and tail quills 28, iii, 1937

Otus manadensis-group, which Stresemann ('40) regards as the races of scops, is distributed in Celebes (typical form) and the Moluccas. The present race is known from Batjan, Halmahera and Morotai.

\title{
PSITTACIDAE
}

Subfamily Loriinae

Eos-Trichoglossus-Oenopsittacus relation.

These groups share a few morphologically similar characters, though are distinct in color system :

1) Bill character is almost exactly the same.

2) Tail feathers are soft and broad in Eos and Oenopsittacus, a little stiffer and narrower, and the tail is sharply cuneated in Trichoglossus.

3) Primaries are stiff and narrow in Eos, similar or more or less broad in Trichoglossus, and are soft and broad in Oenopsittacus. The wing formular is similar.

4) Dark bars of the breast characteristic in Trichoglossus can be found in Oenopsittacus but is lost in Eos.

The tail feathers, at least in Trichoglossus, are round tipped in the male and pointed in the female.

In distribution, Trichoglossus occupies from Australia, Timor-Group, Celebes, Amboina-Group, Papuan Is., New Hebrides and New Caledonia; Eos from the Moluccas, Sanghir Is., Papuan Is., Tenimber and Solomon Is., while Oenopsittacus is a Micronesian (Caroline Is.) aberrant.

Genus Eos Wagler, 1832

Type, Psittacus histrio P.L.S. Müller

86. Eos squamata guenbyensis (Scopoli)

Psittacus Guenbyensis Scopoli, Del. Flor. et Faun. Insubr., fasć. 2, 1786, p. 87 (Halmahera. cf. Peters, iii, p. 146).

$\begin{array}{lll}\text { Halmahera } & \circ & 18, \text { xii, } 1934 \\ & \delta, 2 \circ \circ, 1 \text { unsexed } & 5-12, \text { ii, 28, ii }-5, \text { iii, } 1935\end{array}$




$$
\begin{array}{ll}
\text { 엉ㅇ } & \mathrm{x}, \mathrm{xi}, 1936 \\
2 \text { 우우, 우 juv. } & 4,6,26, \mathrm{v}, 4, \mathrm{vi}, 1937
\end{array}
$$

The species is distributed in the Western Papuan Islands to the Moluccas.

In two sf ecimens (Nos. 18408, 18409) the purple collar and the same color of the abdomen are almost continuous, and therefore, the red band is incomplete, while in the others there is a broad red breast band (about $2 \mathrm{~cm}$.). The purple occipital patch is continuous to the purple collar and the undar tail-coverts are purple or more or less reddish.

Eos squamata (?)insularis Guillemard

Eos insularis Guillemard, Pr. Z.S. London, 1885, p. 565, pl. 34 (Weeda Is.).

$$
\begin{array}{cc}
\text { Halmahera } 2 \text { क } & 18, \text { xii, } 1934 \\
\text { Wing } 136+\mathrm{x}, 139.5 & \text { Tail }-, 81.5
\end{array}
$$

These two specimens differ from the preceding race in having broader $(3 \mathrm{~cm}$. red breast band, only a small occipital patch not continuous to the purple collar which are paler and duller than in guenbyensis, and red rather than purple under tail-coverts. These characters are to be attributed to the race insularis which has not been recorded from Halmahera. It is to be added that a specimen of typical guenbyensis was collected with the above two insularis examples on the same date, 18, xii, 1934.

\section{Genus Trichoglossus Vigors and Horsfield, 1827 (1926)}

Type, Psittacus haematod Linné

\begin{tabular}{|c|c|c|}
\hline Celebes (Minahasa) & $\delta$ & 17, iv, 1937 \\
\hline & s, 5 우 우 & $4,5,6,14,15,18$, v, 1938 \\
\hline & $2 \xi \hat{\beta}$, 웅 & $7,15,17$, vii, 1938 \\
\hline & 4 홍, 2 우우 & $6,7,8,9,28$, viii, 1938 \\
\hline & 1 unsexed & undated \\
\hline Wing 123-131 & Tail $76.5-87$ & Culmen 18.8-20.6 \\
\hline Tarsus $17-18.5$ & & \\
\hline " Moluccas Is." & unsexed & undated \\
\hline Wing 120.5 & ail 73 & Tarsus 15 \\
\hline
\end{tabular}

\section{Trichoglossus ornatus (Linné)}

Psittacus ornatus Linné, Syst. Nat., ed, 10, 1, 1758, p. 98 (Celebes. cf. Peters, iii, p. 148).

The species is known from Celebes and Togian Is., Peling, Banggai and But on. The above "Moluccas Is." specimen is a very small example and with olivaceous upperparts, not as greenish as in Celebes series. This may be an unknown race?

Genus Psittenteles Bonaparte, 1854

Type, Trichoglossus versicolor Lear 
88. Psittenteles flavoviridis meyeri (Walden)

Trichoglossus Meyeri Walden, Ann. and Mag. Nat. Hist., (4), 8, 1871, p. 281 (Menado, Celebes).

Celebes unsexed undated

A species restricted to Celebes and Sula Is. (typical race).

Genus Domicella Wagler, 1832

Type, Psittacus domicella Linné

(Lorius Vigors, 1825 (L. domicella) is preoccupied by Larius

Boddaert, 1783 (L. roratus), an apparent error for Lorius)

89. Domicella garrula garrula (Linné)

Psittacus garrulus Linné, Syst. Nat., ed. 10, 1, 1758, p. 100 (Halmahera. cf. Peters, iii, p. 155).

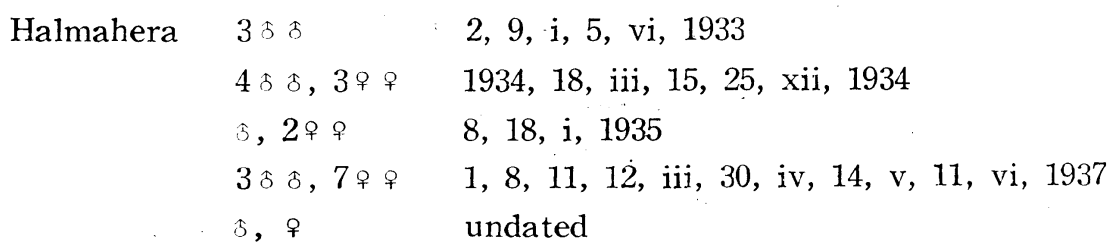

Wing 163-179 Tail 103.5-112.5 Culmen 22-25.5

No locality (Halmahera !) 8 unsexed undated

The species inhabits Halmahera and Weda Is. (garrula, with small dorsal yellow patch), and Morotai, Raou, Batjan and Obi (flavopalliata, with larger yellow patch).

\section{Genus Charmosyna Wagler, 1832 \\ Type, Psittacus papou Scopoli}

90. Charmosyna placentis intensior (Kinnear)

Hypocharmosyna placentis intensior Kinnear, Bull. B.O.C., 48, 1928, p. 84 (Batjan).

$$
\begin{array}{lll}
\text { Halmahera } & 5,+\circ & \text { ix, } 1936 \\
& \circ & 25, \text { viii, } 1938
\end{array}
$$

A Moluccan race of the species which is found also in New Guinea and Papuan Is.

Subfamily Cacatuainae

Genus Cacatua Brisson, 1760

Type, Cacatua alba, fide Vieillot, 1817

(ex Brisson)

91. Cacatua alba (P.L.S. Müller) 
Psittacus albus P.L.S. Müller, Natursyst., Suppl., 1776, p. 76 (Moluccan Is.).

$\begin{array}{lll}\text { Halmahera } & 2 \delta \delta & 24, \text { xii, } 1934 \\ & \uparrow & 9, \text { i, } 1935 \\ & \text { क } 2 \text { unsexed } & 3, \text { mid., ix, } 1936 \\ 4 \% \subsetneq & 8,9,12, \text { iii, } 1937 \\ 2 \delta \delta, 2 \text { unsexed } & \text { undated }\end{array}$

Wing 259-285 (11 spec.)

No locality (Halmahera !) 12 unsexed undated

Wing 264-298 (11 spec.)

The species is only known from the Moluccas.

Subfamily Psittacinae

Genus Lorius Boddaert, 1783

Type, Psittacus roratus P.L.S. Müller

92. Lorius roratus vosmaeri Rosthchild

Larius roratus vosmaeri Rosthchild, Ann. and Mag. Nat. Hist. (9), 9, 1922, p. 412 (N. Moluccas).

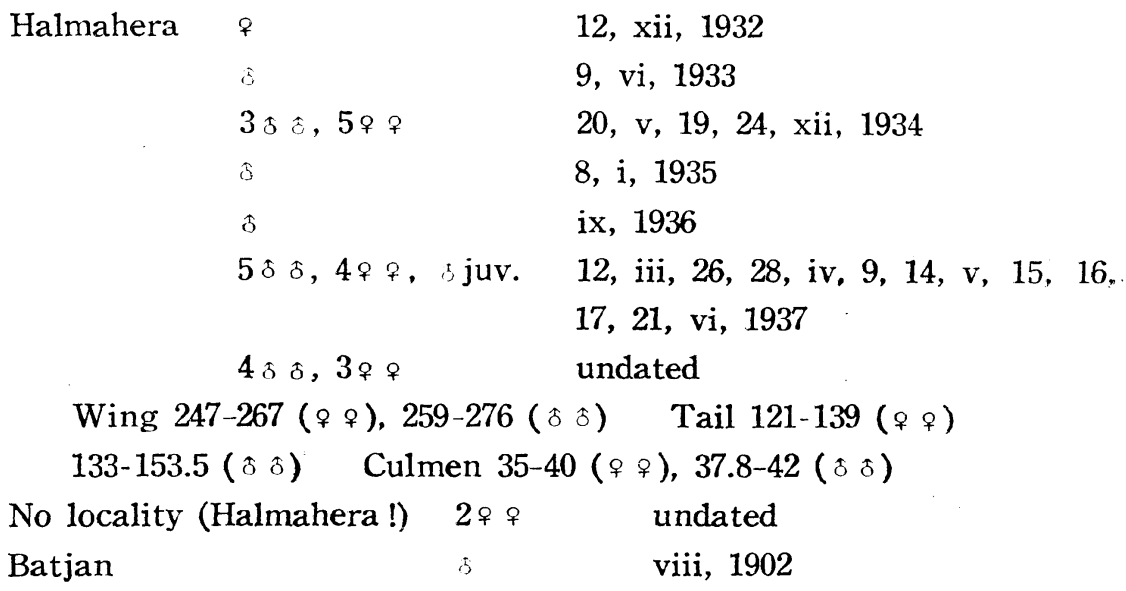

This is a north Moluccan race of the Austro-Moluccan species, L. roratus. A specimen (No. 34080) is of female color, being red above and purple below, but few green feathers (or green-tipped feathers on the back) are mixed particularly on the head and upper tail-coverts. The bill is black with small red basal part. This may be a young male.

There are two L. r. roratus (Ceram), and two L. r. pectoralis (New Guinea) in the Meseum collection. The males are similar, but the female pectoralis differs from roratus in the slightly yellowish tip of the tail, more purplish under parts and larger purple eye-ring. They form a group characterized by the purple eyering, red under tail-coverts and bluish underparts in the females, while $L$. $r$. 
vosmaeri is characterized by yellower color of the male, redder back in the female, as well as yellow under tail-coverts and tail-tip and reddish purple underparts and neck-ring, lacking also purple eye-ring. The size is larger than the other two races.

Genus Geoffroyus Bonaparte, 1910

Type, Psittacus geoffroyi Bechstein

93. Geoffroyus geoffroyi cyanicollis (S. Müller)

Psittacus cyanicollis S. Müller, Verh. nat. gesch. Ned., Land-en Volkenk., pt. 4, 1841, p. 108 (Menado, error $=$ Moluccas).

\begin{tabular}{|c|c|c|}
\hline Halmahera & $\hat{o}$ & vii, 1931 \\
\hline & ㅇ & xi, 1932-vii, 1933 \\
\hline & 하, 3 우 웅 & 20,29, i, 15, ii, 9, vi, 1933 \\
\hline & $\hat{\delta}, \quad$ ㅇ & 1934, 18, iii, 1934 \\
\hline & $3 \hat{f} \hat{\delta}, 2$ 우우 & $6,15, \mathrm{i}, 5-12, \mathrm{ii}, 1935$ \\
\hline & “q” ( $\delta !)$ & ix, 1936 \\
\hline & 6 항, 3 우의 & $8,9,11,12$, iii, 10, v, 1937 \\
\hline & $\delta$ & 26 , vii, 1938 \\
\hline & 6 하옹, 6 우우 & undated \\
\hline
\end{tabular}

Wing 167-174 (우), 168-178 ( $\delta \delta$ ) Tail 90.5-97, 107 (․ㅜ),

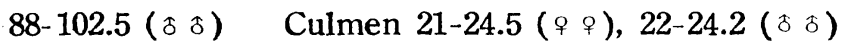

No locality (Halmahera!) $2 \hat{\delta} \hat{s}, \quad+\quad$ undated

The species is distributed in the Moluccas, Sunda Is., New Guinea to West Papuan Is., and has never been recorded from Celebes.

Genus Prioniturus Wagler, 1832

Type, Psittacus platurus Vieillot

94. Prioniturus flavicans Cassin

Prioniturus flavicans Cassin, Pr. Acad. Nat. Sci. Phil., 6, 1853, p. 373 (Celebes). Celebes (Mongondo) 2 우 6, v, 13, vi, 1938

The species ranges from the Philippines to N. Celebes. Peters and Hachisuka (Bds. Phil.) recognize the races, montanus and verticalis, but according to Stresemann ('40) they are not separable.

95. Prioniturus platurus platurus (Vieillot)

Psittacus platurus “Temm." Vieillot, Nouv. Dict. Hist. Nat. 25, 1817 (1818),

p. 314 (New Caledonia, error=Celebes, fide Peters).

Celebes (Menado, Minahasa)

$$
\begin{array}{ll}
\text { ㅇ } & 9, \text { viii, } 1937 \\
2 \delta \delta, 2 \odot \subsetneq ~ & 12,14, \mathrm{v}, 1938
\end{array}
$$


This is a Celebesian species also found in adjoining islands, with another race in Talaut Is.

Note: P. flavicans has black tip of the tail and a blue patch on the head, $P$. platurus has dark-blue tip of the tail and the head is grey with a red spot, having also a orange neck-ring, while another species discurus of the Philippines is related with flavicans having black tip of the tail but the whole head is blue, and is smaller in size.

Genus Tanygnathus Wagker, 1832

Type, Psittacus megalorhynchus Boddaert

96. Tanygnathus sumatranus sumatranus (Raffles)

Psittacus sumatranus Raffles, Trans. Linn. Soc. London, 18, 1822, p. 231

(Sumatra: description of female). cf. Stresemann, O.M.B., 1938, p. 149. Celebes (Celebes, Mongondo)

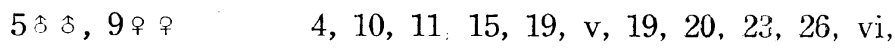

$$
\begin{aligned}
& 8,31 \text {, vii, 1, 20, viii, } 1938
\end{aligned}
$$

A species of from the Philippines to Celebes and the adjoining islands, the present race being principally Celebesian.

97. Tanygnathus megalorhynchos subsp.?

Cf. Peters, iii, p. 240-1; Hachisuka, Bds. Philip., iii, pl. ii ; L'Ois. et la Rev. fr. d'Orn., 1935, pp. 214 8 .

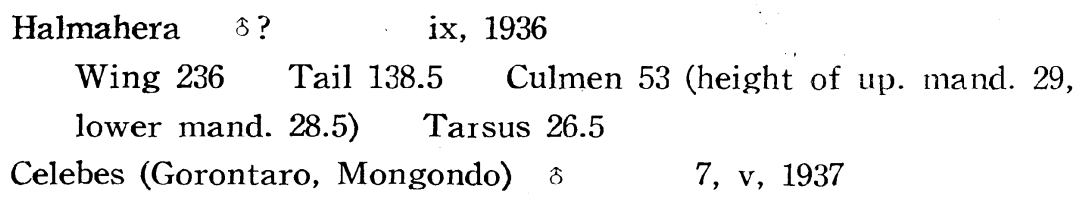

Wing 234 Tail 184 Culmen 46.5 (height of up. mand. 24 lower mand. 24.5) Tarsus 25

The two specimens are similar generally in color except that the one from Halmahera (in fresh plumage) is purer in blue color of the rump, which is extended to the lower back. In Celebesian specimen (in used plumage) the blue is faded and the lower back is greenish as the upper back. In size the latter is smaller particularly in the bill.

Peters includes Halmahera and small islands off the northern peninsula of Celebes as well as Batjan, Obi, etc. in the range of T. m. megalorhynchos, but Hachisuka ('35) describes races: $T \cdot m$. batchianensis (Batjan, Mysol. wing 5240 254, +240 , tail $\$$ 150-165, + 145) and $T$. $m$. obiensis (Obi. wing is 235 245, tail 145-147). For Salawatti, Batanta, Halmahera and Waigiou ? he refers the much smaller original race (wing \& 220,232 ).

The above two specimens agree generally with his batchianensis or megalorhyn- 
chos in the prevailing blue color, but the under tail-coverts are not washed with blue as he remarks. According to Mayr ('41) the N. Moluccan race is megalorhynchos (cf. Pr. Acad. Nat. Sci. Phil., 1939, pp. 148-9- not referred).

Genus Loriculus Blyth, 1850

Type, Psittacus galgulus Linné

98. Loriculus stigmatus stigmatus (S. Müller)

Psittacus (Psittacula) stigmatus S. Müller, Verh. nat. gesch. Nederl., Land-en Valkenk., pt. 6, 1843, p. 182 (Celebes).

Celebes (Minahasa) $\quad 853,7$ 우 $\quad 8, \mathrm{v}, 16, \mathrm{vi}, 17,18,19,23$, 24,29 , vii, $15,19,23,25$, viii, 1938

An endemic Celebesian species with only another race in Togian Is.

(to be continued) 